\title{
Kezdeti tapasztalataink sacralis neuromodulációval az idiopátiás vizeletretenció kezelésében
}

\author{
Romics Miklós dr. ${ }^{1}$, Kiss Gusztáv dr.2 , Erőss Lóránd dr. ${ }^{3}$, Nyirády Péter dr. ${ }^{1}$, \\ Majoros Attila dr. ${ }^{1}$ \\ 'Semmelweis Egyetem, Urológiai Klinika és Uroonkológiai Centrum, Budapest (igazgató: Nyirády Péter dr.) \\ 2Innsbrucki Orvostudományi Egyetem, Neuro-urológiai Ambulancia, Innsbruck, Ausztria \\ ${ }^{3}$ Országos Klinikai Idegtudományi Intézet, Funkcionális idegsebészet, Budapest (igazgató: Erőss Lóránd dr.)
}

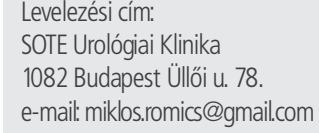

\section{ÖSSZEFOGLALÁS \\ Bevezetés és célkitüzés: A sacralis neuromoduláció (SNM) a vizeletretencióval járó nem obstruktív eredetű húgy- hólyag-diszfunkció (sokszor hipokontraktilis) alternatív kezelési lehetősége. Célunk volt bemutatni a sacralis neuromodulációval szerzett kezdeti tapasztalatainkat, eredményeinket.}

Betegek és módszer: Munkacsoportunk részletes kivizsgálást követően 3 betegnél (két nő: 26 és 42 éves, egy férfi: 41 éves) végezte el Interstim Neuromodulátor (Medtronic, USA) implantációját. Mindhárom betegnél nem obstruktív eredetű detrusor hipokontraktilitást igazolt az urodinamikai vizsgálat. A férfi betegnél gerincsérv miatt történt korábban mütét és ennek következményeként jelentkeztek a vizelési panaszok, míg a két női beteg anamnézisében a panaszokat magyarázó érdemi organikus eltérést nem észleltünk, az idiopátiás eredet mellett felmerült a Fowler-szindróma lehetősége is. A neuromoduláció előtt mindegyik beteg intermittáló önkatéterezést végzett, spontán vizeletüritésre képtelenek voltak. A férfi betegnél a katéterezések között akaratlan vizeletvesztés is előfordult, illetve széklettartási zavara is volt. Konzervatív kezelések eredménytelenek voltak. A sacralis neuromoduláció indikációjának felallitását követően a betegeket két lépcsőben operáltuk. Elöször intraoperatív tesztstimulációt követően bevezettük az elektródákat a sacralis foraminákon keresztül és a legjobb funkcionális választ adó helyzetben rögzítettük őket. Minden esetben kétoldali tesztelést választottunk. Ezt követően két-három hetes tesztperiódus után elemeztük a vizelési naplók eredményét és a jó válaszreakció miatt minden betegnél elvégeztük a végleges neuromodulátorok beültetését. Férfi betegünknél egy darab, kétoldali stimulációt lehetővé tevő neuromodulátort, míg női betegeinknél $2-2 \mathrm{db}$, egyegy oldalt vezérlő neuromodulátort ültettünk be.

Eredmények: A kétoldali neuromodulációt követően minden beteg spontán vizelése beindult. A fiatalabb női beteg reziduummentesen ürítette hólyagját, ezért az intermittáló önkatéterezést elhagyta. A másik két beteg vizeletürítése szintén javult, a katéterezések száma és a visszamaradó vizeletmeny-

\section{Preliminary experiences with sacral neuromodulation in the treatment of non-obstructive urinary retention}

\section{SUMMARY}

Introduction and aims: In our study we proudly present our initial experiences with sacral neuromodulation (SNM) in the treatment of non-obstructive urinary retention trough detrusor hypocontractility.

Patients and methods: Three of our patients, diagnosed with non-obstructive detrusor hypocontractility, have been chosen for the implantation of Interstim neuromodulators (Medtronic, USA) after a thorough urological, neurological and gynecological examination. The male patient (41) received surgery for a spinal herniation before he developed the condition, the two female patients ( 26 and 42 ) had no past history to explain their voiding inability: the cause could be interpreted as idiopathic or symptom of Fowler's syndrome. All our patients were doing intermittent selfcatheterisation 4-5 times a day before the neuromodulation, the conservative treatment methods all failed to improve their situation. After we have demonstrated solid evidence for the indication of SNM, we performed it in two steps: at first - after the bilateral implantation of the sacral electrodes through the sacral 3-4 foramen - we have performed a 2-3 weeks long testmodulation to analyse the effects of the stimuli. The modulation kick started the spontaneous miction for each patient therefore the implantation of the definitive subcutaneous neuromodulator could be performed.

Results: After the implantation of the stimulating devices, the youngest patient could discontinue self-catheterisation, and the others did not need to do it more than 3 times a day (from the initial 5-6). After the operations we did not experience any complications or pain symptoms. 
nyiség csökkent. Átlagosan napi 3 alkalommal végeznek önkatéterezést. A beavatkozások után komplikációt, jelentős mértékű fájdalmat nem észleltünk.

Következtetés: A sacralis neuromoduláció a nem obstruktív eredetű vizeletretenció kezelésének jó, minimálisan invazív alternatívája lehet. Válogatott esetekben, részletes kivizsgálást és megfelelő indikációt követően hipokontraktilis húgyhólyagfunkció esetén eredményesen alkalmazható.

\section{KULCSSZAVAK}

SACRALIS NEUROMODULÁCIÓ, VIZELETRETENCIÓ, DETRUSOR

HIPOKONTRAKTILITÁS, FOWLER-SZINDRÓMA

\section{Bevezetés}

A funkcionális, vagyis nem obstruktív eredetú vizeletrekedés mechanizmusának megértése és kezelése hosszú ideje jelent kihívást a neuro-urológia számára (1). A hetvenes években még gyakran pszichogén, vagy hisztériás eredetúnek tartották a problémát, és a kezelési algoritmusát is ez határozta meg (2). A korábbi terápiás megoldások főleg gyógyszeres és konzervatív módszereket jelentettek: kismedencei relaxációs tréning, biofeedback, alfa-blokkolók, izomrelaxánsok, vagy antidepresszánsok kombinációját, ritkábban húgycsőtágítást és hólyagnyaki bemetszést (3). Ezen eljárások kimenetelét sokkal inkább jellemezte frusztráció és kudarc, mint a spontán vizelési készség helyreálítása. Hatásos kezelési módszer hiányában csak az intermittáló önkatéterezés nyújthatott elviselhetó életkörülményeket a spontán vizelésre képtelen betegeknek. A kilencvenes években azonban a sacralis gyökerek neuromodulációja is felmerült lehetséges megoldásként, és az ezredfordulót követően már több tanulmány is megjelent és bizonyította hatását a nem obstruktív vizeletretenció és a sürgősségi vizeletinkontinencia/hiperaktív hólyagszindróma kezelésében (4-6). Az utóbbi években a sacralis neuromoduláció már egy gyakran alkalmazott és jól bevált megoldásnak számít, és már olyan - korábban a kezelés kontraindikációját képező - kórképekben, mint a sclerosis multiplex, is eredményesnek bizonyult. Fontos, hogy emellett - szemben egyes tévhitekkel - a terhességre sincs káros hatással $(7,8)$. Hazánkban elsőként 2009-ben, a Pécsi Tudományegyetemen Pytel és munkatársai (9) végeztek sacralis neuromodulációt vizeletürítési zavarok kezelésére. Írásunkban az első három, intézetünk égisze alatt, multidiszciplináris team által végzett beavatkozásokról számolunk be, érintve a neuromoduláció elméleti alapjait, betegszelekciót, kivizsgálást, a tesztstimulációt és implantációt, valamint az utánkövetés és kontroll lépéseit.
Conclusion: SNM is an effective and minimal invasive alternative solution for non-obstructive urinary retention. After a thorough examination and careful patient selection it can be successfully applied for treating hypocontractile detrusor function.

\section{KEYWORDS}

SACRAL NEUROMODULATION, URINARY RETENTION, DETRUSOR HYPOCONTRACTILITY, FOWLER'S SYNDROME

\section{A sacralis neuromoduláció}

A sacralis neuromoduláció (SNM) kifejlesztését Tanagho és Schmidt végezték az 1980-as évek elején (10). Ök bizonyították elsőként, hogy a hármas sacralis ideggyök (továbbiakban S3) folyamatos stimulációja a detrusor izomzat és a húgycső-sphincter aktivitására és a vizelési reflex kiváltására is hatással van a gerincvelói reflexek és perifériás afferensek ingerlésén keresztül. A hólyag-sphincter záró reflexének elnyomásával csökkenti a záróizom tónusát és ezzel segíti a vizeletürítést, a fiziológiás afferentáció helyreállításával pedig a hólyag-teltségérzet központi idegrendszeri tudatosulása is visszatér, amely következetesen erősíti a detrusorfunkciót és így a hólyagürítést segíti (11). Késztetéses panaszok esetén pedig a fenti módszert a detrusoraktivitás gátlására fordíthatjuk, a kifolyási húgycsőellenállás, vagy a detrusorkontrakció erejének csökkentése nélkül is. A két ellentétes hatásmechanizmus pontos alapját nem ismerjük, de két teória létezik.

- Mikciós reflexek reorganizációja: Az afferensek folyamatos, ritmikus stimulációjával bénítja az idegkisülést, csökkentve a tárolási reflexet, és elösegíti a vizeletürítést.

- Rebound-effektus: A mélyebb, stimulátorfrekvencia elnyomja a mikciós reflexet. Ennek hirtelen kikapcsolása kiváltja (engedi) a vizeletürítést (12). Ezt a gyakorlatban is alkalmazzuk, amikor a beteget megkérjük, arra, hogy vizeletürítés előtt kapcsolja ki a stimulátort.

A fentiek ismeretében már logikusan következik, hogy az SNM felhasználható hiperaktív hólyagszindróma/sürgősségi inkontinencia és nem obstruktív vizeletrekedés kezelésében egyaránt. Emellett a kismedencei fájdalomszindróma kezelésében is szerepet kaphat, habár még egyelöre csak off-label kezelési megoldásként (13). A sacralis neuromoduláció hosszú távú hatékonyságát - tekintettel a különböző körképekre és azok esetlegesen eltérő fokú súlyosságára - a nemzetközi iro- 
dalom széles határok között adja meg. A siker- és gyógyulás ráta hiperaktivitásra jellemző hólyagtünetek esetén 20-33\%tól 60-70\%-ig változik, idiopátiás vizeletrekedés esetében pedig 58-73\% közötti értéket mutat (14). SNM során kialakuló szövődmények általában ritkák és nem súlyosak: az elektródok elmozdulásának, és a modulátorok mechanikai meghibásodásának előfordulása 10\% alatti, az implantációt követő fájdalom és diszkomfortérzés (24-34\%) gyakran enyhe és nem tartós (15).

\section{Betegek és módszer}

A három, későbbiekben sacralis neuromodulációval kezelt beteg kivizsgálása klinikánk Kontinencia Centrum és Urodinamikai Laboratóriumában kezdődött meg.

Első betegünk, a 41 éves családapa, vegetatív tünetekkel jelentkező gerincsérv-operációját követően került látókörünkbe: a kiszakadt lumbális gerincsérv miatt vizeletretenciója és székletürítési zavara jelentkezett, amely a sérvmútét után sem rendeződött. A katéterezések között akaratlan vizeletvesztése is előfordult, illetve intermittálóan széklettartási probléma is fellépett. Nőbetegeink (26 és 42 évesek) viszont nem rendelkeztek neurológiai, vagy urológiai anamnézissel - náluk az idiopátiás eredet mellett az úgynevezett Fowler-szindróma (a záróizom relaxációs képtelensége, szisztémás neurológiai betegség nélkül) lehetősége is felmerült. A konzervatív (gyógyszeres, illetve fizioterápiás) kezelések gyakorlatilag eredménytelenek voltak, az intravesicalis elektrostimuláció pedig csak a hólyag szenzoros funkcióján javított, a motoros készséget nem befolyásolta, fiatalabb nőbetegünk pedig egyáltalán nem tolerálta a kezelést. SNM irányában történő kivizsgálásuk kezdetén már minden betegünk intermittáló önkatéterezést végzett.

Urológiai vizsgálatuk - vizelési napló, vér- és vizeletvizsgálat, ultrahang, cystometria nyomás-áramlás vizsgálattal, cisztoszkópia, - neurológiai, idegsebészeti (fizikális vizsgálat, gerinc MRI), aneszteziológiai és nőgyógyászati állapotfelméréssel párhuzamosan zajlott. (A Fowler-szindróma mellett 50 százalékban jelen lévő policisztás ovárium jelenléte egyik nőbetegünkben sem került leírásra) (16). Az urodinamikai vizsgálatot minden betegnél ugyanazzal az Andromeda Ellipse 4 (Andromeda AG, Németország) készülékkel végeztük el; mindhárom betegnél nem obstruktív eredetú detrusor hipokontraktilitást igazolt a mérés. Ezt követően többlépcsős, részletes felvilágosítást adtunk a betegeknek és átlátható, egyértelmű kezelési stratégiát és időbeosztást készítettünk, ezzel is érthetőbbé, kézzelfoghatóbbá téve a betegek számára a komplikált, hazánkban új módszernek számító beavatkozást. Ennek keretében minden beteget referáltunk az Innsbrucki Orvostudományi Egyetem Neuro-urológiai Ambulanciáját vezető főorvosnak, dr. Kiss Gusztávnak, és az Országos Klinikai Idegtudományi Intézet Funkcionális Idegsebészet osztályvezető főorvosának, dr. Erőss Lórándnak. Amennyiben a beavatkozást és annak lépéseit, esetleges szövődményeit a betegek elfogadták és írásos belegyezésüket adták, megkezdhettük az sacralis neuromoduláció előkészítését.

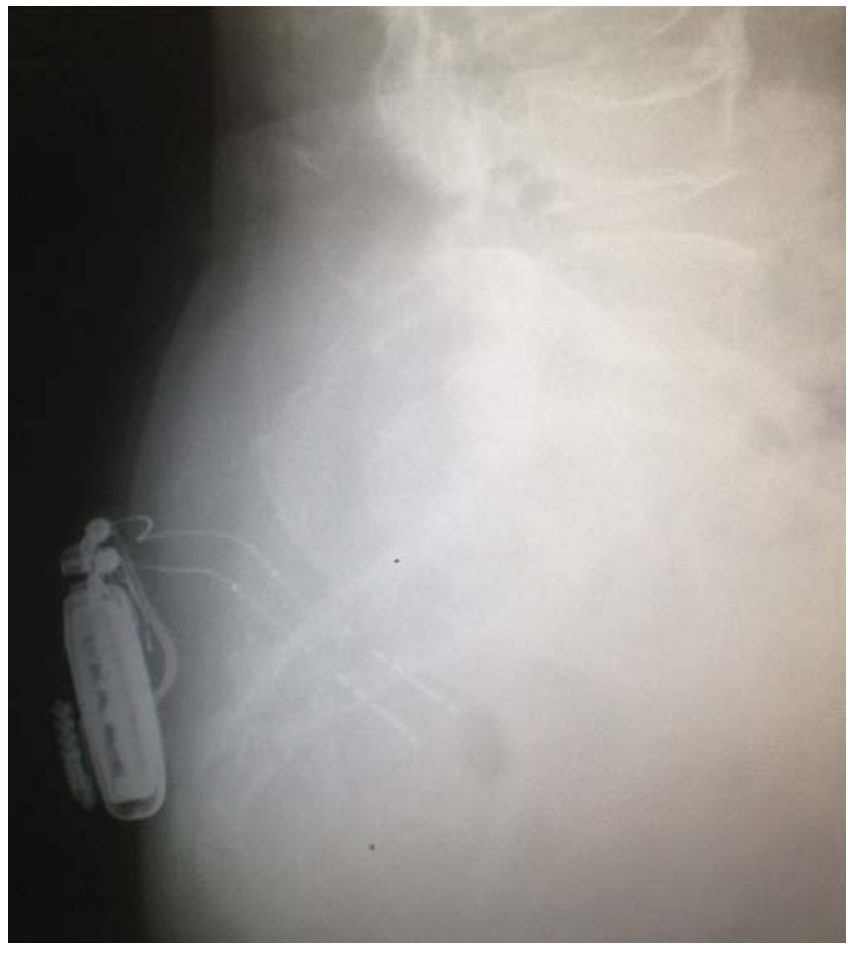

1. Ábra: OldalirÁnyú SACRUm RÖntgenfelvÉTEL: A SACRALIS STIMULÁCIÓT KÖZVETÍTŐ ELEKTRÓdOK AZ S3 ÉS S4 FORAMENEKBEN, VALAMINT A KÜLSÖ (HORDOZHATÓ) NEUROMOdULÁTOR (VERIFY EVALUATION SYSTEM, Medtronic USA). Tesztstimuláció alatti Állapot

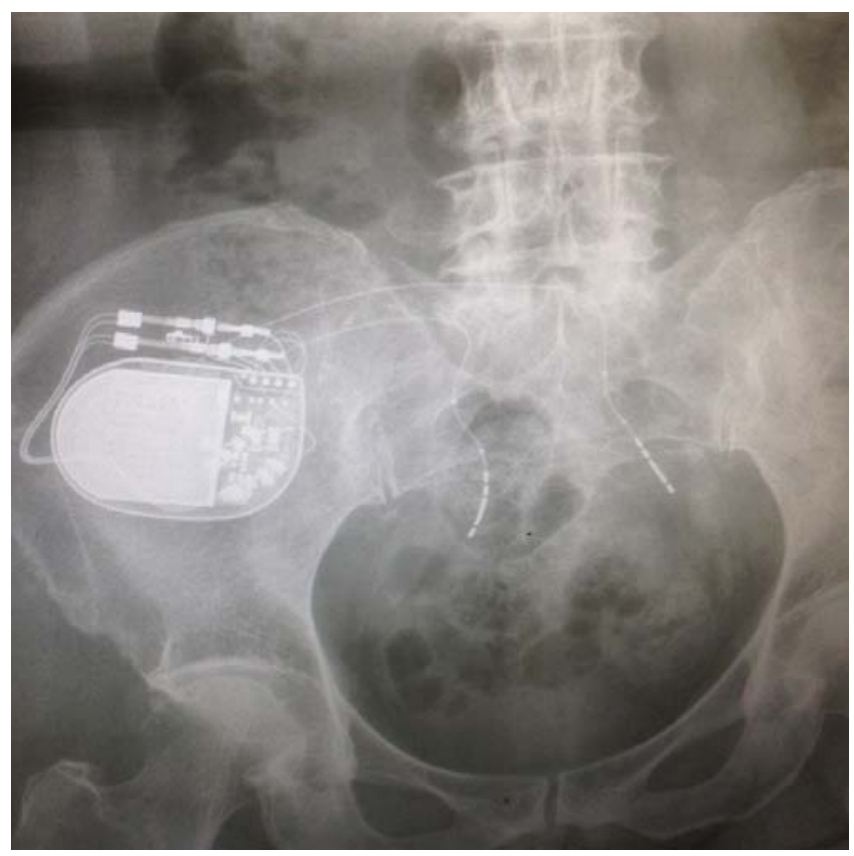

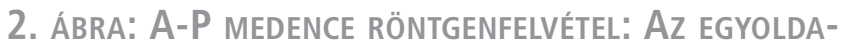
LI, KÉTCSATORNÁS SACRALIS NEUROMODULÁTOR

(Interstim I Neurostimulator, Medtronic USA) És A KÉT SACRALIS ELEKTRÓD A VÉGLEGES NEUROMUDULÁTOR BEÜLTETÉST KÖVETŐEN 
A beavatkozás minden esetben az Országos Klinikai Idegtudományi Intézetben történt idegsebész vezetésével, urológus segédletével, illetve jelenlétével. Első lépésben intraoperatív tesztstimulációt végeztünk a kétoldali sacralis foraminákon (S3-4), röntgencélzással bevezetett elektródákon keresztül (kipróbálva a mono- és bipoláris elvezetéseket, mélyebb és magasabb szinteken, különböző frekvenciákon), majd a legjobb funkcionális választ adó helyzetben (ahol legjobban volt látható a musculus levator ani kontrakciója és legkevésbé az ipsilaterális hallux flexiója) rögzítettük azokat. Ezen helyzetben volt várható a hólyag és a húgycső-sphincter múködését leginkább befolyásoló neuromoduláció. A posztoperatív szakban oldalirányú kismedencei röntgenfelvétellel kontrolláltuk az elektródák megfelelő pozícióját (1. ábra). Az elektródákat az operáció után külső, hordozható és a beteg által távirányítással vezérelhető modulátorokhoz kötöttük (Verify Evaluation System, Medtronic, USA), amelyeket a beteg a derekán viselt az elkövetkezendő háromhetes tesztperiódus alatt. A betegeket megkértük, hogy kapcsolják ki a stimulátort a vizelés alatt; a mélyebb, folyamatos stimulátorfrekvencia ugyanis elnyomja a mikciós reflexet, ennek hirtelen kikapcsolása viszont engedi annak kiváltódását (12). Az első két hétben a két oldalt különkülön teszteltük, a harmadik héten pedig a kettőt együtt - az ún. Innsbruck algoritmus szerint (17). Ennek során vizelési naplót készíttettünk betegeinkkel, hogy eldönthessük, alkalmasak-e (panaszok, tünetek szignifikáns javulása alapján) a végleges, subcutan neurostimulátor beültetésére. A tesztperiódus alatt mindhárom betegnél megindult a spontán vizeletürítés Mind a három beteg határozott javulást tapasztalt az életminőségben és igényt mutattak a végleges neuromodulátorok beültetésére is. (A végleges modulátor beültetésének feltétele, a spontán ürített vizeletmennyiségben, vagy a vizeletretenciók volumenében tapasztalt, legalább 50 százalékos pozitív javulás.) Tekintettel a szubjektív és objektív javulásra a neuromodulátorok végleges beültetése mellett döntöttünk.

Férfi betegünknél egy darab, kétoldali stimulációt lehetővé tevő úgynevezett twin-neuromodulátort (Interstim I Neurostimulator, Medtronic, USA) (2. ábra), míg női betegeinknél 2-2 db egy-egy oldalt vezérlő neuromodulátort (Interstim II Neurostimulator, Medtronic, USA) ültettünk be. Ezen technikai különbség csupán a mútétek hosszában jelentett némi változást, a stimulátorok karakterében, funkcionális paramétereiben nem volt különbség. Férfi betegünk operációja 2013 szeptemberében, míg hölgy betegeink mútétjére 2016 júniusában került sor. A posztoperatív szakban mútéti szövődmény, sebfertőzés nem jelentkezett, és a neuromodulátorokat (N’Vision Clinician Programmer, Medtronic, USA segítségével) a mútétet követő második napon üzembe helyeztük (3. ábra). A betegek a bőr alá ültetett eszközökhöz is távirányítót kaptak, hogy be és kikapcsolhassák, illetve növelhessék/csökkenthessék a moduláció erősségét, amennyiben arra a továbbiakban szükség volt. Az aktiválást követően két, majd nyolc hétnél történt személyes kontroll (4. ábra), emellett pedig a betegekkel folyamatos telefonos kapcsolatban álltunk, hogy az esetleges szövődményekről is tudomást szerezhessünk. Ezt követően a betegeket további rendszeres kontrollvizsgálatok-

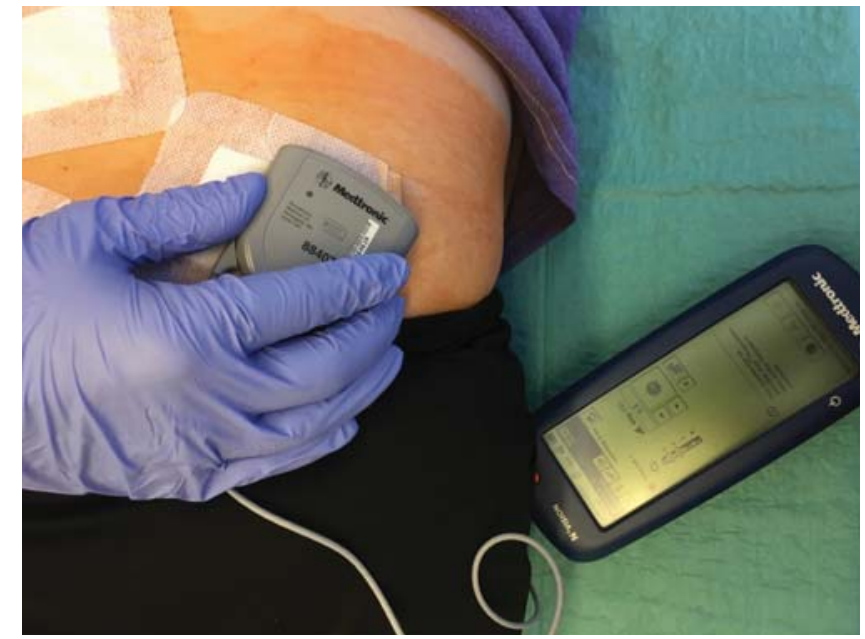

3. ÁBRA: AZ INTERSTIM NEUROMODULÁTOR TRANSZKUTÁN BEÜZEMELÉSE ÉS BEÁlLítÁSA NVISION CLINICIAN Programmer (Medtronic, USA) Segítségével

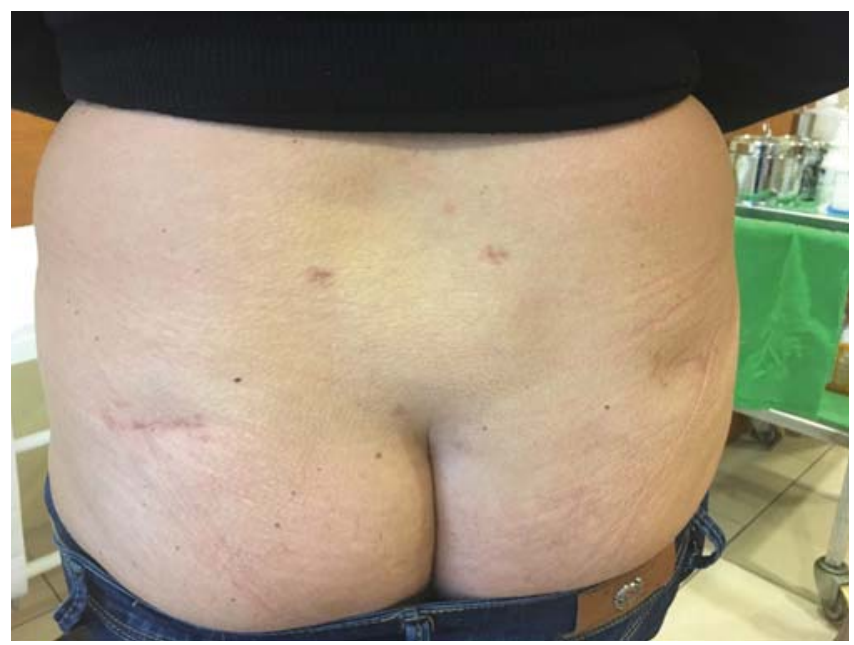

4. ÁBRA: AlIg LÁTHATÓ MUUTÉTI HEGEK A KÉTOLDALI SACRALIS NEUROMODULATOR (INTERSTIM II NEUROStimulator, Medtronic USA) BeÜltetése után 2 HÓNAPPAL

kal követtük, illetve követjük. A beültetett neuromodulátorok akkumulátorának kimerülése és ez alapján történő cseréje - a beállításoktól függően - pedig csak 6-8 év múlva várható. A mútéteket antibiotikum-profilaxisban végeztük.

\section{Eredmények}

A tesztstimulációt követően minden betegnél beindult a spontán vizelés, a subcutan modulátorok beültetése után, a folyamatos stimuláció hatására pedig tovább nőtt a spontán ürített vizeletmennyiség mértéke. A fiatalabb nőbeteg resziduummentesen ürítette hólyagját, ezért az intermittáló önkatéterezést elhagyta. A másik két beteg vizeletürítése 
szintén javult, a katéterezések száma és a visszamaradó vizeletmennyiség csökkent: 40, illetve 50 százalékos spontán vizeletmennyiség mellett napi 3 alkalommal szorultak önkatéterezésre, a korábbi 5-6 helyett. A férfi beteg obstipációja is javult. A beavatkozások után szövődményt, perzisztáló fájdalmat, neurológiai komplikációt nem észleltünk, a kezelt betegek minden esetben hasznosnak találták a beavatkozást, és ha újra választaniuk kellene, egyértelmúen a modulátor beültetése mellett döntenének ismét. Habár a vizsgálat előtt, nagy esetszámú vizsgálatoktól eltérően nem jelöltünk ki szigorú paramétereket, amelyek alapján a neuromodulációt sikeresnek vagy sikertelennek ítélhettük volna, a spontán vizeletürítés megindulása és az önkatéterezések számának markáns csökkenése, valamint a szövődmények elmaradása és a betegek elégedettsége mind arra utal, hogy a három beavatkozás sikeres volt és ugyanezen betegszelekciós, vizsgálati és operációs algoritmusok a továbbiakban is alkalmazhatók (18).

\section{Megbeszélés}

A sacralis neuromoduláció egy a nemzetközi és hazai ajánlásokban szereplő, széles körben elismert, jól használható, jól tolerálható és kis szövődményrátával járó beavatkozás, amely alkalmazható a terápiarezisztens hiperaktív hólyagszindróma/urge inkontinencia másodvonalbeli kezelésében és a nem obstruktív eredetű vizeletretenció terápiájában is (19, 20). Mint korábban említettük nem ismerjük a pontos patofiziológiai mechanizmusát a módszernek, amely két teljesen ellentétes tünettan (vizelettartási és -ürítési zavar) kezelésére egyaránt szolgálhat. Tekintettel arra, hogy az OAB/urge inkontinencia másodvonalbeli kezelésében az SNM mellett a botulinum toxin azonos hatékonysággal javasolható, ugyanakkor a vizeletretencióhoz vezető detrusor hipokontraktilitásnak a sacralis neuromoduláción kívül nincs valós, hatékony kezelési alternatívája, elsősorban ezen betegek kezelésében javasoljuk alkalmazni ezen terápiás módszert. Nem véletlen, hogy a sacralis neuromodulációt urológiai indikációval hazánkban elsőként alkalmazó pécsi munkacsoport is hipo-/akontraktilis hólyagmüködés és következményes vizeletretenció kezelésére végezte az első beavatkozásokat. A szerzők a Magyar Urológus Társaság 2011-es kongresszusán ismertették pozitív tapasztalataikat. Minthogy a teljes folyamat, a kivizsgálástól a posztoperatív kontrollig felettébb bonyolult és részben tisztázatlan patofiziológián alapul, a kezelési algoritmus talán legérzékenyebb pontja a körültekintő betegválasztás és részletes felvilágosítás. Jó eredményeket akkor érhetünk el, ha a hólyagfunkció miogén komponensei nem, vagy csak kevéssé károsodtak, illetve az urodinamikai vizsgálat a detrusor izomzat kontraktilitásának legalább részleges megmaradását mutatja (hipokontraktilitás). Detrusor akontraktilitás esetén lényegesen kisebb esély van a javulásra. Amennyiben a vizeletretenció korábbi alsó húgyúti obstrukció talaján, a hólyagizomzat kimerülése, tehát miogén eredetű károsodása következtében alakul ki, nincs remény a mútétet követő javulásra. A betegkiválasztás alatt a legfontosabb szempontunk tehát annak eldöntése, hogy a hólyagizomzat miogén eredetű károsodása valószínúsíthető-e. Ez részben az anamnézisből (pl. elhanyagolt prosztata-obstrukció okozta jelentős mértékű vizeletretenció), a hólyagdekompenzációt okozó alsó húgyúti obstrukció endoszkópos igazolásából, továbbá a cisztometriát követő nyomásáramlás vizsgálat során végezhető speciális tesztek alapján (jeges víz teszt, betanechol teszt, húgyhólyag-agy kiváltott potenciál vizsgálat) igazolható. Amennyiben a beteg nem kellöen kooperatív, nem várható kielégítő eredmény a sacralis neuromodulációtól. Az általunk operált esetekben a betegek tisztában voltak az esetleges kudarc lehetőségével és szövődmények előfordulásával, és azt is előre deklaráltuk, hogy a későbbiekben feltehetően még szükségük lehet (bár csökkentett számban) önkatéterezésre is. A kiegyensúlyozott orvos-beteg kapcsolat és kölcsönös bizalom fontos lépcsője az SNM hoszszú távú sikerének. Továbbá fontos kiemelnünk az intézetek közti kooperáció szerepét is: rendkívül szerencsésnek mondhatjuk magunkat, hogy a neuro-urológia és a funkcionális idegsebészet egy-egy kiemelkedő képviselője segítette munkánkat és a továbbiakban is partnernek tekinthetjük őket! Három beteg alapján természetesen nem lehet messzemenő következtetéseket levonni, azonban az általunk tapasztalt javulás mértéke és a szövődmények aránya megfelel a nemzetközi irodalomban közölt adatoknak. Swinn 2000-ben 38, vizelési diszfunkció miatt neuromodulált beteg esetét vizsgálta és 68\%-ban találta sikeresnek a beavatkozást. Vizsgálatában a spontán vizelés megindulása volt az elsődleges végpont (21). Van Kerrebroeck 2007-ben ismertette 5 éves, multicentrikus prospektív vizsgálatuk eredményét: 31 retenciós beteg stimulációja során 71\%-ban tapasztaltak szignifikáns változást a spontán ürített vizelet mennyiségében és önkatéterezések számában (22). Chartier-Kastler 2011-es vizsgálatukban 151, vizeletrekedés miatt InterStim készülékkel kezelt beteg adatait elemezte és 77\%-ban találta sikeresnek (az önkatéterezések száma szignifikánsan csökkent) a beavatkozást, de leírja a metódus hosszú távú (60 hónapos követés utáni) eredményességét, és a 60-80\% közötti elégedettségi arányt is (23). Végül pedig egy 2014-es publikációban olvashatunk a sacralis neuromoduláció hatásosságáról ismeretlen okú vizeletretenció esetén: Elneil és munkacsoportja már a tesztstimuláció harmadik hetében is nagy arányban tapasztalták a vizelési inger visszatértét (90\%) és a spontán vizelés beindulását (80\%) (24).

\section{Következtetés}

A nem obstruktív eredetű vizeletretenció sacralis neuromodulációs kezelésével szerzett szerény kezdeti tapasztalataink megfelelnek a nemzetközi irodalomban közölt eredményeknek. Ennek alapján a módszert alkalmasnak tartjuk a nem obstruktív, ismeretlen eredetú, detrusor hipokontraktilitásra visszavezethető vizeletretenció kezelésére. 


\section{Irodalom}

1. Aboseif S, Tamaddon K, Chalfin S, et al. Sacral neuromodulation in functional urinary retention: an effective way to restore voiding BJU Int 2002; 90(7): 662-5. https://doi.org/10.1046/j.1464410X.2002.02989.x

2. Barrett D. Psychogenic urinary retention in women. Mayo Clin Proc 1976; 51: 351-6.

3. Trockman BA, Gerspach J, Dmochowski R, et al. Primary bladder neck obstruction. urodynamic findings and treatment results in 36 men. J Urol 1996; 156: 1418-20. https://doi.org/10.1097/00005392199610000-00047 https://doi.org/10.1016/50022-5347(01)65605-2

4. Wang Y, Zhou Y, Mourad MS, Hassouna MM. Neuromodulation reduces urinary frequency in rats with hydrochloric acid-induced cystitis. BJU Int 2000 Oct; 86(6): 726-30. https://doi.org/ 10.1046/j.1464-410x.2000.00873.x

5. Grüenewald V, Jonas U. Neurostimulation for lower urinary tract voiding problems. Curr Urol Rep 2000 Oct; 1(3):199-203. https://doi.org/10.1007/s11934-000-0019-z

6. Chancellor MB, Chartier-Kastler EJ. Principles of Sacral Nerve Stimulation (SNS) for the Treatment of Bladder and Urethra Sphincter Dysfunctions. Neuromodulation 2000 Jan; 3(1): 16-26. https://doi.org/10.1046/j.1525-1403.2000.00015.x

7. Marinkovic SP, Gillen LM. Sacral neuromodulation for multiple sclerosis patients with urinary retention and clean intermittent catheterization. Int Urogynecol J 2010 Feb; 21(2): 223-8. https://doi.org/10.1007/s00192-009-1023-6

8. Yaiesh SM, Al-Terki AE, Al-Shaiji TF. Safety of Sacral Nerve Stimulation in Pregnancy: A Literature Review. Neuromodulation 2016 Oct; 19(7): 770-779. https://doi.org/10.1111/ner.12450

9. Pytel Á, Szücs K, Kovács N, Balás I. Detrusor diszfunkciók minimál invazív mútéti megoldása (Botulinum toxin terápia, sacralis neuromoduláció) MUT XVI. Kongresszusa 2011 - poster

10. Tanagho EA, Schmidt RA, Orvis BR. Neural stimulation for control of voiding dysfunction: a preliminary report in 22 patients with serious neuropathic voiding disorders. J Urol 1989; 142: 340-345. https://doi.org/10.1016/50022-5347(17)38751-7

11. DasGupta R, Fowler CJ. Urodynamic study of women in urinary retention treated with sacral neuromodulation. J Urol 2004 171: 1161-1164.https://doi.org/10.1097/01.ju.0000113201.26176.8f

12. Schultz-Lampel D, Jiang C, Lindström S, Thüroff JW. Experimental results on mechanisms of action of electrical neuromodulation in chronic urinary retention. World J Urol 1998; 16(5): 301-304. https://doi.org/10.1007/s003450050071
13. Van Kerrebroeck PE, Marcelissen TA. Sacral neuromodulation for lower urinary tract dysfunction. World J Urol 2012 Aug; 30(4): 44550. https://doi.org/10.1007/s00345-011-0780-2

14. Marcelissen $T$, Jacobs $R$, van Kerrebroeck $P$, de Wachter $S$. Sacral neuromodulation as a treatment for chronic pelvic pain. J Urol 2011 Aug; 186(2): 387-93. https://doi.org/10.1016/j.juro.2011.02.2694

15. Peeters K, Sahai A, De Ridder D, Van Der Aa F. Long-term followup of sacral neuromodulation for lower urinary tract dysfunction. BJU Int 2014 May; 113(5): 789-94. https://doi.org/ 10.1111/bju. 12571

16. Osman NI, Chapple CR. Fowler's syndrome - a cause of unexplained urinary retention in young women? Nat Rev Urol 2014 Feb; 11(2): 87-98. https://doi.org/10.1038/nrurol.2013.277

17. Huwyler M, Kiss G, Burkhard FC, Madersbacher H, Kessler TM. Microbiological tined-lead examination: does prolonged sacral neuromodulation testing induce infection? BJU Int 2009 Sep; 104(5): 646-50; discussion 650. https://doi.org/10.1111/j.1464410X.2009.08501.x

18. Cardarelli S, et al. Efficacy of sacral neuromodulation on urological diseases: a multicentric research project. Urologia 2012 Apr-Jun; 79(2): 90-6. ttps://doi.org/10.5301/RU.2012.9278

19. Az Emberi Erőforrások Minisztériuma szakmai irányelve a felnőttkorban előforduló, nem neurogén eredetű vizeletinkontinenciáról. 2016. EüK. 6. szám EMMI szakmai irányelv (hatályos: 2016.03.30.)

20. Burkhard FC, (Chair), Ucas MG, Berghmans LC, et al. Urinary Incontinence, EAU Guideline 2016.

21. Swinn MJ, Kitchen ND, Goodwin RJ, Fowler CJ. Sacral neuromodulation for women with Fowler's syndrome. Eur Uro 2000 Oct; 38(4): 439-43. https://doi.org/10.1159/000020321

22. van Kerrebroeck PE, et al. Results of sacral neuromodulation therapy for urinary voiding dysfunction: outcomes of a prospective, worldwide clinical study. J Urol 2007 Nov; 178(5): 202934. https://doi.org/10.1016/j.juro.2007.07.032

23. Chartier-Kastler $E$, et al. Sacral neuromodulation with InterStim ${ }^{\mathrm{TM}}$ system: Results from the French national register Prog Urol 2011 Mar; 21(3): 209-17. https://doi.org/10.1016/j.purol.2010.05.008

24. Elneil S, Abtahi B, Helal M, Digesu A, Gonzales G. Optimizing the duration of assessment of stage-1 sacral neuromodulation in nonobstructive chronic urinary retention. Neuromodulation. 2014 Jan; 17(1): 66-70. https://doi.org/10.1111/ner.12017 